\title{
Attitudes of Students Towards Pontius as Immigrants - Foreigners
}

\author{
Konstantinidou Zoe ${ }^{a}$ \\ Kyridis Argyris ${ }^{a}$ \\ Fotiadis Konstantinos ${ }^{b}$ \\ ${ }^{a}$ Aristotle University of Thessaloniki
${ }^{b}$ University of Western Makedonia
}

Doi:10.5901/jesr.2016.v6n1p102

Abstract

Greece is a country with great diversity and cultural pluralism, both during recent decades, in which it has been a host country during a period of intense migration, as well as previously since it was a country of return. Pontius population group has played a significant part in both the aforementioned period first as refugees in 1926 because of the Lausanne treaty and then as repatriates from the former Soviet Union. This research studied the views of students $(N=404)$ of the first and second levels of education, of Pontius as a refugee - foreigner. The results showed that the age and the origin of the students as well as their participation, or not, in culture societies are associated with their attitudes, while the age of the students is associated with racial stereotypes.

Keywords: refugee, foreigner, Pontius Hellenism, attitudes, intercultural education.

\section{Introduction}

Greece is a country that has been a point of departure as well as a destination for many immigration movements throughout its entire history. Most of those immigration movements were compulsory and they occurred due to reasons that were financial in nature. Greek population of Black Sea (Pontius) was part of those movements in two immigration waves. The first was during the population exchange that took place in 1922 and the second was during the repatriation of Pontius from the former Soviet Union that took place from 1982 onwards (Fotiadis, 1995:38). The expatriates of Pontius origin that came to live permanently in Greece from the former Soviet Union during the last few decades, and especially during the period that spans from 1965 until the end of the previous century, are estimated to be more than 230.000 (Kelesidis, 2004:18). During the period between 1989 and 2000 alone, according to the records of the National Institute for the Reception and Restoration of Repatriated Expatriates, 143.066 people were registered in order to take advantage of its various programs (Nirrorg 2001a, 2001b).

Immigration flows have certain innate characteristics that can make social exclusion very easy (Kasimati, 2007). Such characteristics are mainly the low financial level of the people being moved as well as their different cultural background. Once those characteristics are detected, the social differences are identified; the next step is the development of a racial stereotype and detachment, which all lead to social degradation.

According to Allport (1954) and Macrae, Stangor and Hewstone (1996), prejudice should be defined as a dislike that is based on a mistaken, rigid and entrenched generalization, that starts at a very young age and is very difficult to change (Tajel \& Fraser, 1978). It is very often the result of a lack of knowledge and information regarding the characteristics of which otherness consists.

Another characteristic that has always been making the social integration of Pontius is the knowledge of the language (Papakonstantinou \& Dellasoudas, 1997:384-390; Vergeti, 1999:75; Kasimati, 2007). Considering that the knowledge of the language is a core cultural element, a lack of that knowledge has negative effects on the communication and the development of social relations with the indigenous population (Gotovos, Markou \& Fering, 1987:50) as well as on the education of Pontian refugees. Because of the lack of knowledge of the Greek language many Pontius refugees don't develop relations and a significant percentage of them abandon school and education in order to seek work (Kasimati, 2007), which results in the stigma of failure at school. This has been observed to cause a feeling of rejection (Kolaitis, 2005:202-203), that is experienced by the refugees - immigrants as a devaluation of their presence (Vedder et.al, 2006). According to research that was conducted on schools in Attica, a significant percentage of repatriated students, feel insecure and rejected, regarding the attitude of the indigenous population towards repatriated immigrants (Gotovos, Markou \& Fering, 1987:47-55), whom they refer to as "Russians" and refuse to integrate them in their social groups, both in and out of the school (Vergeti, 1999:76). According to Papastyliannoy (2012:36), this attitude 
of the indigenous population was based on the fact that they couldn't integrate the immigrants in either the -inner or the outer group, because of the lack of distinction concerning their lineage and origin. Similar studies that took place in other countries have also shown that the children of immigrants demonstrate increased anxiety and stress, aggression, feelings of loneliness, self - devaluation and are often being rejected when it comes to becoming members of a new group (Asher \& Dodge, 1986: 444-446, Coie, 1992).

A study that took place in the districts of Evros and Rodopi is a classic example of this. According to the findings, the indigenous population of those areas has the tendency of moving their children from schools located in areas in which Pontius refugees have settled, because they believe that the co-existence of indigenous and repatriated children in the same school, greatly downgrades the level of education offered by that school.

The theoretical framework of this study, is based on the fact that actions of an experiential character that are associated with learning through experience (Dewey), as well as through discovery (Bruner) offer students the ability to understand the importance of multiculturalism as well as to develop effective processes that will allow them to test new strategies for analysis and control of the dynamic of the social group in which they belong and to create conditions of empathy, self-reflection and self-awareness (Tsironis,2008:125).

\section{Methodology}

In this study participated 404 students (boys $\mathrm{N}=147$ and girls $\mathrm{N}=230$ ) from 14 schools of the first and second levels of education (Primary school $\mathrm{N}=123$, Middle School $\mathrm{N}=119$ and High School $\mathrm{N}=162$ ) situated in western Thessaloniki (table 1). The students were given a guided tour of an exhibition dedicated to the Hellenism of the Black Sea. A part from traditional exhibits, the exhibition also offered photographic and audiovisual material. One week after their tour, students were asked to write down their thoughts and views regarding the subject of the exhibition through a questionnaire. The questionnaire consisted of two parts. The first part was about students' demographics and the second about the open question "Analyze your views on the subject of the exhibition."

Table 1. Descriptive statistics of sample

\begin{tabular}{lcc}
\hline SEX & N & $(\%)$ \\
\hline CATEGORY & 174 & 43.1 \\
\hline Boys & 230 & 56.9 \\
Girls & 404 & 100.0 \\
Total & & \\
\hline SCHOOL GRADE & $\mathbf{N}$ & $(\%)$ \\
\hline CATEGORY & 123 & 30.4 \\
\hline Primary school & 119 & 29.5 \\
Secondary school & 162 & 40.1 \\
High school & 404 & 100.0 \\
Total & & \\
\hline AREA & $\mathbf{N}$ & $(\%)$ \\
\hline CATEGORY & 329 & 87.4 \\
\hline Pontius refugees & 78 & 18.6 \\
non Pontius refugees & 404 & 100.0 \\
Total & & \\
\hline CULTURAL ASSOSIATION MEMBER & $\mathbf{N}$ & $(\%)$ \\
\hline CATEGORY & 31 & 7.7 \\
\hline Yes & 373 & 92.3 \\
No & 404 & 100.0 \\
\hline Total & & \\
\hline ORIGIN & $\mathbf{N}$ & $(\%)$ \\
\hline CATEGORY & 185 & 45.8 \\
\hline Pontius & 45 & 11.1 \\
Asia Minor & 174 & 43.1 \\
another & 404 & 100.0 \\
\hline Total & & \\
\hline & & \\
\hline
\end{tabular}

The questionnaires produced 1771 references in total. Most of those were filled out by girls (61.8\%) and by students from immigrant areas (79.4\%). The percentage of references concerning the level of the schools (39\% Primary School, $23.6 \%$ Middle School and $37.4 \%$ High School) as well as the origin of the students (45.8\% students of Pontius origin, $42.5 \%$ students of other origin) are relatively even (table 2). 
Table 2. Descriptive statistics of references

\begin{tabular}{lcc}
\hline SEX & & \\
\hline CATEGORY & $\mathbf{N}$ & $(\%)$ \\
\hline Boys & 677 & 38.2 \\
Girls & 1094 & 61.8 \\
Total & 1771 & 100.0 \\
\hline SCHOOL GRADE & $\mathbf{N}$ & \\
\hline CATEGORY & 691 & $(\%)$ \\
\hline Primary school & 418 & 39.0 \\
Secondary school & 662 & 23.6 \\
High school & 1771 & 37.4 \\
Total & & 100.0 \\
\hline AREA & $\mathbf{N}$ & \\
\hline CATEGORY & 1406 & $(\%)$ \\
\hline Pontius refugees & 365 & 79.4 \\
non Pontius refugees & 1771 & 20.6 \\
Total & & 100.0 \\
\hline CULTURAL ASSOSIATION MEMBER & $\mathbf{N}$ & \\
\hline CATEGORY & 155 & $(\%)$ \\
\hline Yes & 1616 & 8.8 \\
No & 1771 & 91.2 \\
Total & & 100.0 \\
\hline ORIGIN & $\mathbf{N}$ & \\
\hline CATEGORY & 812 & $(\%)$ \\
\hline Pontius & 207 & 45.8 \\
Asia Minor & 752 & 11.7 \\
Another & 1771 & 42.5 \\
Total & & 100.0 \\
\hline
\end{tabular}

\section{Findings}

Once the classification of the references was finished, four main categories emerged. These are "Museum education" approach and teaching of historical sources and terms of liking, repetition and the material of the exhibition, "human rights", which concerns the reference to the immigration movement and the immigrants, the morality and the feelings of grief and sorrow to the refugee, "attitudes toward Pontius" which encompasses the knowledge of the culture, the admiration, the empathy and the reference to the origin and finally "racial stereotypes" about Greeks and Turks as victims and victimizers, respectively (Table 3 ).

Table 3. Categories that emerged from the analysis of references

\begin{tabular}{|c|c|c|c|c|c|c|c|c|}
\hline CATEGORY & $\mathbf{N}$ & $(\%)$ & SUBCATEGORY & $\mathbf{N}$ & $\mathrm{N}(\%)$ & I SUBKATEGORY ANALYSIS & $\mathbf{N}$ & $\mathrm{N}(\%)$ \\
\hline \multirow{12}{*}{ Museum Education } & \multirow{12}{*}{489} & & \multirow{4}{*}{ Liking } & \multirow{4}{*}{277} & \multirow{4}{*}{15.6} & Pleasure & 129 & 7.3 \\
\hline & & & & & & Interesting experience & 70 & 4.0 \\
\hline & & & & & & Expressions of interest in exhibition's subject & 22 & 1.2 \\
\hline & & & & & & Pedagogical approach & 48 & 2.7 \\
\hline & & & Repetition & 26 & 16.5 & & & \\
\hline & & \multirow{7}{*}{28.1} & & & & Picture gallery & 84 & 4.7 \\
\hline & & & & & & Photography exhibition & 37 & 2.1 \\
\hline & & & & & & Sculpture exhibition & 1 & 0.1 \\
\hline & & & Education material & 197 & 11.1 & Books-historical sources & 8 & 0.5 \\
\hline & & & & & & Period pieces & 13 & 0.7 \\
\hline & & & & & & Audiovisual material & 9 & 0.5 \\
\hline & & & & & & More than one of the above & 48 & 0.7 \\
\hline \multirow{3}{*}{ Human Rights } & \multirow{3}{*}{416} & \multirow{3}{*}{23.5} & Reference of refugee & 61 & 3.4 & & & \\
\hline & & & Morality & 219 & 12.4 & & & \\
\hline & & & Feelings of sadness & 134 & 7.6 & & & \\
\hline \multirow{6}{*}{$\begin{array}{l}\text { Attitude towards } \\
\text { Pontius }\end{array}$} & \multirow{6}{*}{780} & \multirow{2}{*}{\multicolumn{2}{|c|}{ Knowledge }} & \multirow{2}{*}{238} & \multirow{2}{*}{13.4} & Wrong impression & 202 & 11.4 \\
\hline & & & & & & Attitude change & 34 & 1.9 \\
\hline & & \multirow{4}{*}{\multicolumn{2}{|c|}{$\begin{array}{l}44.0 \\
\text { Admiration }\end{array}$}} & \multirow{4}{*}{317} & \multirow{4}{*}{17.9} & For culture & 123 & 6.9 \\
\hline & & & & & & For religion maintaining & 31 & 1.8 \\
\hline & & & & & & For courage and militancy & 58 & 3.3 \\
\hline & & & & & & For history & 104 & 5.9 \\
\hline
\end{tabular}




\begin{tabular}{|c|c|c|c|c|c|}
\hline CATEGORY & $\mathbf{N}$ & $(\%)$ & SUBCATEGORY & N N (\%) SUBKATEGORY ANALYSIS & $\mathrm{N} \mathrm{N}(\%)$ \\
\hline & & & Empathy & $68 \quad 3.8$ & \\
\hline & & & & 89 Pride in origin & 102 \\
\hline & & & Origin & 8.9 Origin reference (of non Pontius) & 3.1 \\
\hline \multirow{2}{*}{ Racial Stereotypes } & \multirow{2}{*}{77} & \multirow{2}{*}{4.3} & Reference Greeks as victims & 1.1 & \\
\hline & & & Reference Turkish as perpetrators & 57 & \\
\hline Total & 1171 & 100.0 & & 1771100.0 & 1179100.0 \\
\hline
\end{tabular}

Three four categories mentioned above, showed statistically significant differences ("Museum education" sig $=.000$, "attitude toward Pontius" sig $=.000$ and "racial stereotype" sig $=.044, p<.05$ ). The last two seemed to have a statistically significant correlation with the factor "education level". Additionally the second category seemed to have a significant correlation with the factors "origin or origin of the subjects"' and" active participation in cultural institutions" (Table 4).

Table 4. Sig. categories

\begin{tabular}{lllccc}
\hline CATEGORY & FACTOR & Df & F & Sig. \\
\hline \multirow{3}{*}{ Museum education } & \multirow{2}{*}{ School grade } & between groups & 10 & & \\
& & within groups & 456 & 9.7 & .000 \\
& \multirow{3}{*}{ Racial stereotype } & Total & 466 & & \\
& \multirow{2}{*}{ School grade } & between groups & 7 & & \\
& & within groups & 75 & 4.2 & .044 \\
& & Total & 76 & & \\
\hline
\end{tabular}

The references of the category "racial stereotype" were split in two sub-categories that emphasized the aspect of the victim and the victimizer. It was noted that the racial stereotypes are more prevalent in very young ages and they focus mainly on the role of the victimizer. As the age of the subjects grew however, so did the focus on the role of the victim. It should definitely be noted that those references seem to be greatly affected by the historical sources that students are taught at school, which identify the Greeks of Pontus as Greeks. The references of the category "attitude towards Pontius" on the other hand show that students, regardless of their age, don't have full knowledge of the history of Pontius Hellenism. This fact greatly affects their view towards Pontius. It should also be noted that new information acquired on the subject of the history of Pontius Hellenism leads to admiration and a change or shift in attitude. Children of younger ages experience facts with a greater emotional intensity and they display greater empathy. However, as the children become older, the concept of origin becomes clearer and more understood and the students use it as a declaration of identity and pride (table 5).

Table 5. Stereotype race and attitudes to Pontius according to the school level

\begin{tabular}{|c|c|c|c|c|c|}
\hline CATEGORY & SUBCATEGORY & & SCHOOL GRADE & & TOTAL \\
\hline \multirow{4}{*}{ Race stereotype } & \multirow[b]{2}{*}{ Greeks as victims } & Primary school & Secondary school & High school & \\
\hline & & $\begin{array}{c}7 \\
15.6 \%\end{array}$ & $\begin{array}{c}8 \\
44.4 \%\end{array}$ & $\begin{array}{c}5 \\
35.7 \%\end{array}$ & $\begin{array}{c}20 \\
26.0 \%\end{array}$ \\
\hline & \multirow{2}{*}{ Turkish as perpetrators } & 38 & 10 & 9 & 57 \\
\hline & & $84.4 \%$ & $55.6 \%$ & $64.3 \%$ & $74.0 \%$ \\
\hline \multirow{2}{*}{ Total } & & 45 & 18 & 14 & 77 \\
\hline & & $100.0 \%$ & $100.0 \%$ & $100.0 \%$ & $100.0 \%$ \\
\hline \multirow{8}{*}{ Attitudes to Pontius } & \multirow{2}{*}{ New information } & 77 & 56 & 105 & 238 \\
\hline & & $28.4 \%$ & $31.3 \%$ & $31.9 \%$ & $30.6 \%$ \\
\hline & \multirow{2}{*}{ Admiration } & 113 & 84 & 120 & 317 \\
\hline & & $41.7 \%$ & $46.9 \%$ & $36.5 \%$ & $40.7 \%$ \\
\hline & \multirow{2}{*}{ Empathy } & 41 & 4 & 22 & 67 \\
\hline & & $15.1 \%$ & $2.2 \%$ & $6.7 \%$ & $8.6 \%$ \\
\hline & \multirow[t]{2}{*}{ Origin } & 40 & 35 & 82 & 157 \\
\hline & & $14.8 \%$ & $19.6 \%$ & $24.9 \%$ & $20.2 \%$ \\
\hline \multirow{2}{*}{\multicolumn{2}{|c|}{ Total }} & 271 & 179 & 329 & 779 \\
\hline & & $100.0 \%$ & $100.0 \%$ & $100.0 \%$ & $100.0 \%$ \\
\hline
\end{tabular}

Regarding the attitude towards Pontius in relation to the origin of the students, it is obvious that the highest rates are those concerning in the sense of wonder that students have developed through the new information they received. The 
necessity of this new information was equally indicated by students of all levels of education. It should be noted that students that are of Asia Minor origin, seemed to have more empathy for Pontius Hellenism. They connect better with the plight of the Pontius because of their similar experiences and emotional burden, since they also arrived in Greece via an immigration movement (table 6).

Table 6. Attitudes to Pontius on the origin

\begin{tabular}{|c|c|c|c|c|c|}
\hline CATEGORY & SUBCATEGORY & & ORIGIN & & TOTAL \\
\hline \multirow{9}{*}{ Attitude to Pontius } & \multirow{3}{*}{ New information } & Pontos & Asia minor & Other & \\
\hline & & 105 & 23 & 238 & 238 \\
\hline & & $28.0 \%$ & $25.6 \%$ & $30.6 \%$ & $30.6 \%$ \\
\hline & \multirow{2}{*}{ Admiration } & 147 & 32 & 317 & 317 \\
\hline & & $39.2 \%$ & $35.6 \%$ & $40.7 \%$ & $40.7 \%$ \\
\hline & \multirow{2}{*}{ Empathy } & 21 & 14 & 67 & 67 \\
\hline & & $5.6 \%$ & $15.6 \%$ & $8.6 \%$ & $8.6 \%$ \\
\hline & \multirow{4}{*}{ Origin } & 102 & 21 & 157 & 157 \\
\hline & & $27.2 \%$ & $23.3 \%$ & $20.2 \%$ & $20.2 \%$ \\
\hline \multirow[t]{2}{*}{ Total } & & 375 & 90 & 779 & 779 \\
\hline & & $100.0 \%$ & $100.0 \%$ & $100.0 \%$ & $100.0 \%$ \\
\hline
\end{tabular}

Finally, a special mention should be made about the fact that no change or shift was noted regarding the knowledge and therefore the change of attitude and creation of feelings of wonder between students that actively participate in cultural institutions and students who don't. The only significant difference seems to be on the importance that the members of each group attribute to their origin (table 7).

Table 7. Attitude to Pontius in connection with participation in cultural activities

\begin{tabular}{|c|c|c|c|c|}
\hline CATEGORY & SUBCATEGORY & & CULTURAL ORGANIZATION MEMBER & TOTAL \\
\hline \multirow{7}{*}{ Attitude to Pontius } & \multirow{3}{*}{ New information } & ME $\wedge O \Sigma$ & MH ME $\wedge O \Sigma$ & \\
\hline & & 19 & 219 & 238 \\
\hline & & $20.9 \%$ & $31.8 \%$ & $30.6 \%$ \\
\hline & Admiration & $\begin{array}{c}38 \\
41.8 \%\end{array}$ & $\begin{array}{c}279 \\
40.6 \%\end{array}$ & $\begin{array}{c}317 \\
40.7 \%\end{array}$ \\
\hline & Empathy & $\begin{array}{c}3 \\
3.3 \%\end{array}$ & $\begin{array}{c}64 \\
9.3 \%\end{array}$ & $\begin{array}{c}67 \\
86 \%\end{array}$ \\
\hline & \multirow{3}{*}{ Origin } & 31 & 126 & 157 \\
\hline & & $34.1 \%$ & $18.3 \%$ & $20.2 \%$ \\
\hline Total & & $\begin{array}{c}91 \\
100.0 \%\end{array}$ & $\begin{array}{c}688 \\
100.0 \%\end{array}$ & $\begin{array}{c}779 \\
100.0 \%\end{array}$ \\
\hline
\end{tabular}

\section{Discussion}

School nowadays is a cradle of civilizations and its goal is to teach students to appreciate cultural diversity (Banks, 2004), since it is the second most important socialization context, the family being the first for each student (Bronfenbrenner, 1996). Each person's personality is formed during the early years of his or her life. That is why the early school age is considered extremely crucial as far as the formation of stereotypes is concerned.

During this age, opinions are formed through imitation of models that can usually be found among the close familial and social environment. The knowledge found therein also plays a crucial art in the forming of opinions in that age. This results in the development of false and flawed images regarding the profile of a person or group, based on often incomplete information. This initial school experience and the quality of the relationship that the children have developed and experienced will almost definitely be transferred to the subsequent school levels (Duncan \& Cohen, 1999). This is demonstrated in this study by the rapid and immediate change of attitude of the students towards refugees after they come into contact with their history and learn more about it. When knowledge comes as a result of experiential learning, then experiences are created among the members that participated in the "process" of acquiring that knowledge. These experiences in turn create common bonds, emotional as well as social. Thus, the experience and the direct relation of the subject with the place where it is being presented create indelible experiences that have significant 
effects on the attitudes and values of future adults. Thus, the otherness can become familiar and gain not only its own voice, but respect that as well. According to Grant and Secada (1990:148) the greater the exposure and the more time spent on getting to know and to learn the intercultural content borne by the "other" the more successful his or her integration will be. The teachers are also responsible for this, because many times they become frightened of sociocultural diversity and thus they ignore or overlook the existence of cultural influences in the classroom (Gay, 2002), which results in them addressing diversity through an incomplete and flawed framework that promotes inequality (Ross and Smith, 1992).

Of equal or greater importance is also the fact that children of younger ages seem to be especially affected too much by the way in which history is presented throughout the educational system. The views are formed through the modules taught within history class, seem to be strong and to reinforce national stereotypes. What is really interesting, is that younger children mainly focus the part of the victimizer, while older children and students, focus on the victim as well as they focus on the victimizer. This is probably due to empathy, through which the older students are trying to put themselves in the victim's position and see things through their perspective. This is further reinforced by the view of Hunter and Elias (1999) that the treatment of the other is based on emotional reactions to interpersonal attraction.

It is also noteworthy that as the students get older, they start to assume their national identities, which leads to the precise indication of their origin with pride. The concept of identity is multidimensional. It starts with the acceptance of a subject's existence in the world, in the past, the present and the future and it involves the perception of similarity in spatiotemporal continuity and the simultaneous perception that others to recognize this similarity and continuity (Erikson, 1968). The identity depends upon the involvement of the individual in relationships with other people within various social groups, which contribute positively or negatively, through the interdependence of their members (Catwright, D. \& Zander, 1968), the interactions between the members (Bonner, 1934), their common needs (Cattell, 1946) and their concept of integration. Thus, a strong cultural identity has proven to be highly functional for one's personal well-being and it is positively associated with the ability of immigrants to adjust to their host country (Vedder et.al, 2006). The cultural identity specifically, is characterized by a lack of stability, a problematic unity (Vryzas, 1997:183-193) and a complexity in the conditions of the identification process. It seems to be more intense among students that originate from the same country or from countries that are close to each other. However, it is even more intense among students whose ancestors have shared the same or similar experiences. According to Smith (1991) a nation is defined through its culture, while the latter is marked by its history. We see, then, that the common elements of the familial environment can bring closer people of the same intercultural group. According to the social identity theory of Tajfel and Turner (1979) the self-determination of the individual involves issues such as the assessment of the impact that his or her origin in the indigenous population and it defines and influences one's national identity.

What is truly odd or even paradoxical, is the fact that students who actively participate in cultural institutions have developed a sense of origin, which has not been created through a deeper knowledge of their history. It seems that they remain in the development of stereotypes which are formed and cultivated in those specific institutions.

\section{Conclusions}

All of the facts mentioned above highlight the need for proper teaching of history, through experiential and interactive methods, which will develop the critical thinking of students and will help them distance themselves from prejudices and stereotypes of the older generations. The attempt to understand and interpret events through the context of social interaction, can provide solutions to problematic situations of the modern educational reality and formulate a functional social group. What is also obvious is the need for cultural operators to transmit culture through meaningful actions and not just through surface involvement with folklore that only serves the preservation of traditions.

\section{Refereces}

Allport, G. W., (1954). The nature of prejudice. Oxford: Addison-Wesley.

Asher, S. \& Dodge, K., (1986). «ldentifying children who are rejected by their peers». Developmental Psychology, 22, 444-449.

Banks, J., (1994). An introduction to multicultural education. Boston: Pearson, Allyn \& Bacon

Bonner, H., (1934). Group dynamics: Principles and applications, Ronald Press, New York 1959 kaı Mead, G.H., Mind, self and society, The University of Chicago Press, Chicago

Bronfenbrenner, U., (1996). The Ecology of Human Development. Experiments by Nature and Design. Cambridge: Harvard University Press

Catwright, D. \& Zander, A., (1968). Group dynamics, Tavistock, London. 
Cattell, R., (1946). Description and measurement of personality, Harrap, London

Coie, J. D. (1992). «Towards a theory of peer rejection». In S. Asher \& J. D. Coie (Eds), Peer rejection in childhood. New York: Cambridge University Press: 365-403

Duncan, M.K. \& Cohen, R., (1999). Liking within the peer group as a function of children's sociometric status and sex. Child Study Journal, Vol. 25(4), 265-288

Erikson, E-H., Identity: Youth and Crisis, Norton, New York 1968

Fotiadis, K., (1995). The Greeks of the former Soviet Union. The genesis of the Diaspora. In The Greeks of the former Soviet Union (History - Education), Fotiadis, K., (Eds), Thessaloniki: Kyriakydis Brothers, 11-39 (in Greek)

Gay, G. (2002), "Preparing for culturally responsive teaching", Journal of Teacher Education, Vol. 53 No. 2, pp. 106-16.

Gotovos, A., Markou., G. \& Fering, M., (1987) School reintegration of repatriated pupils. A first approach. Contemporary Education 35 , 49-54 (in Greek)

Grant, C. and Secada, W. (1990), Preparing teachers for diversity. In Houston, W.R., Haberman, M. and Sikula, J. (Eds), Handbook of Research on Teacher Education, Macmillan, New York, 403-22

Hunter, L. \& Elias, M. (1999): Interracial friendships, multicultural sensitivity and social competence. Journal of Applied Developmental Psychology, 20, 551-573

Kailaris, I., (1995). Pontiac 'repatriates' of Naoussa (Operation Golden Fleece). In Fotiadis, K., (Eds) The Greeks in the countries of the former USSR (History - Education). Thessaloniki: Kyriakydis Brothers, 145-148 (in Greek)

Kasimati, K., (1998b) Pontic in Greece and social exclusion. In Kasimati, K., (Eds) Exclusion: The Greek experience, Panteion University of Social and Political Sciences. Athens: Gutenberg (in Greek)

Kelesidis, G., (2004). Cultural Diversity and the image of the "Other" in Greek society and our educational system. In Sakka, D. and Psalti, A., (Eds) Cultural diversity in schools: the role of the teacher. Proceedings of the Conference. Alexandroupolis: Ministry of Education and Democritus University of Thrace (in Greek)

Kolaitis, G., (2005). Psychosocial health of children repatriated from the former Soviet Union. In Papastylianou, A., (Eds) Intercultural journeys: Repatriation and psychosocial adjustment.Athens:Ellinika Grammata, 195-214 (in Greek)

Macrae, N, C., Stangor, C. \& Hewstone, M., (1996). Stereotypes and Stereotyping. NY: Guilford Press

National Institute reception and rehabilitation Overseas and Repatriated Greeks (EIYAAПОE) (2001a) Annual Report 1991-2001. Athens (in Greek)

National Institute reception and rehabilitation Overseas and Repatriated Greeks (EIYААПОЕ) (2001b) statistics monitoring chartered EІYААПОЕ housing. Komotini 1991-2001. Athens (in Greek)

Papakonstantinou, Th. And Dellasoudas, L., (1997). The problem of education of foreign students in our country. Motion troubleshooting. In Vamvoukas, M. and Hourdakis, A., (Eds) Pedagogical Science in Greece and in Europe: Trends and Prospects, Proceedings of the International Conference Z, Educational Society - University of Crete. Athens: Ellinika Grammata, 384-396 (in Greek)

Papastylianou, A., (2012). Why palinostountes? Why Greeks? In Intercultural Journeys. Papastylianou, A., (Eds) Athens: Gutenberg, 1744 (in Greek)

Ross, D.D. and Smith, W. (1992), Understanding pre-service teachers' perspective on diversity, Journal of Teacher Education, 43-2, 94103

Smith, D., A. (1991). National Identity. University of Nevada Press

Taifel, H. \& Fraser, C. (1978). Introducing social psychology. UK: Penguin Books

Tajfel, H. \& Turner, J. (1979). An integrative theory of intergroup conflict. In W.G. Austin \& S. Worchel (eds.), The Social Psychology Across Cultures. London: Prentice Hall

Tsironis, X., (2008). Social interaction and social relations at school. The teacher's role in the integration of students. In Driver Training, Education and Intercultural Education, Papanaoum, Z. (Eds), Thessaloniki: Ministry of Education and Religious (in Greek)

Vakalios, A. \& Tzoulis, A. (1999). Repatriation and integration of education as a key factor in the smooth integration of repatriated Pontic Greeks in Greece. Vakalios, A. (Eds) Thessaloniki: Paratiritis (in Greek)

Vedder, P., Horenczyk, G., Liebkind, K., Nickmans, G., (2006). Ethno-culturally diverse education settings, problems, challenges and solutions. Educational Research Review 1 (2006) 157-168

Vryzas, K., (1997). Global Communication. Cultural Identities. Athens: Gutenberg (in Greek) 